\title{
Epiphytic microalgae community as aquatic bioindicator in Brantas River, East Java, Indonesia
}

\author{
SULASTRI ARSAD ${ }^{1,2,3, \boldsymbol{v}}$, KHABIB TAUFIQ PUTRA ${ }^{4}$, NURUL LATIFAH ${ }^{5}$, MIFTAHUL KHAIR KADIM ${ }^{6}$, \\ MUHAMMAD MUSA ${ }^{1,34 \%}$ \\ ${ }^{1}$ Program of Aquatic Resources Management, Faculty of Fisheries and Marine Science, Universitas Brawijaya. Jl. Veteran, Malang 65145, East Java, \\ Indonesia. Tel.: +62-341-553512, Fax.: +62-341-556837, `email: sulastriarsad@ub.ac.id \\ ${ }^{2}$ MicroBase Research Group, Graduate Program, Universitas Brawijaya. Jl. Veteran, Malang 65145, East Java, Indonesia \\ ${ }^{3}$ AquaRES Research Group, Faculty of Fisheries and Marine Science, Universitas Brawijaya. Jl. Veteran, Malang 65145, East Java, Indonesia. \\ Tel.: +62-341-553512, Fax.: +62-341-556837, "“email: musa_fpi@ub.ac.id \\ ${ }^{4}$ Faculty of Fisheries and Marine Science, Universitas Brawijaya. Jl. Veteran, Malang 65145, East Java, Indonesia \\ ${ }^{5}$ Department of Aquatic Resources, Faculty of Fisheries and Marine Science, Universitas Diponegoro. Jl. Prof. Soedarto, SH, Tembalang, Semarang \\ 50275, Central Java, Indonesia \\ ${ }^{6}$ Department of Aquatic Resources Management, Fisheries and Marine Science Faculty, Universitas Negeri Gorontalo. Dulalowo Timur, Gorontalo \\ 96138, Gorontalo, Indonesia
}

Manuscript received: 20 March 2021. Revision accepted: 27 June 2021.

\begin{abstract}
Arsad S, Putra KT, Latifah N, Kadim MK, Musa M. 2021. Epiphytic microalgae community as aquatic bioindicator in Brantas River, East Java, Indonesia. Biodiversitas 22: 2961-2971. One way to monitor water quality is by using biological indicators, namely epiphytic microalgae (periphyton). This study aims to analyze the epiphytic periphyton community structure and analyze the river health status using a saprobic index. The research location was in the Brantas River, Blitar District, East Java, Indonesia. The method used was a survey with sampling at three sites based on the purposive sampling technique. Periphyton samples were taken using the quadrant transect $\left(5 \times 5 \mathrm{~cm}^{2}\right)$ method and then identified using the Lackey Drop Micro transect Counting Method. The results show that the periphyton community structure is in balance, and there are six divisions of 59 different genera. The six divisions found are Bacillariophyta, Cyanophyta, Chlorophyta, Charophyta, Ochrophyta, and Rhodophyta. The most identified genus is from the Bacillariophyta Division with 28 genera, while the least identified genus is the Rhodophyta division with 1 genus. The abundance ranges from $242,800-1,229,174$ cells. $\mathrm{cm}^{-2}$, the relative abundance index of periphyton ranges from 3-60\% (site 1), 9-57\% (site 2), 1-62\% (site 3 ), the diversity index ranges from 1.212-2.617 (moderate), the uniformity index ranges from 0.307-2.151 (high), the dominance index ranges from 0.105-0.549 (moderate), and the saprobic index ranges from-0.18 to 0.55. Moreover, supporting water quality parameters are still optimal, except for ammonia and total organic matter parameters that exceed the quality standard. Based on the saprobic value obtained, the water quality of the Brantas River in Tawangrejo Village can be classified into the category of $\alpha / \beta$-mesosaprobic to $\beta$ mesosaprobic saprobic levels with mild to moderate levels of pollution.
\end{abstract}

Keywords: Lotic water, periphyton, pollution, saprobic, water quality status

\section{INTRODUCTION}

Monitoring and management of the Brantas River must be conducted to maintain the quality of the Brantas River so that it does not exceed the threshold and cause pollution. The monitoring of water quality can use various methods, one of which is using biological indicators (Liyana et al. 2019; Hutami et al. 2020). The benthic macroinvertebrates, fish, and periphyton collections are more often used as biological indicators (Tan and Beh 2015). Periphyton is an example of a bioindicator that can be used to determine the quality of waters. Epiphytic periphyton as bioindicators is very effective and economical because periphyton has advantages compared to other organisms. Periphyton has a wide distribution in water, plays an essential role in the food chain, has a short life cycle, reproduces quickly, is found in almost all substrates, is the primary producer in the food chain, and can withstand heavy currents. Most periphyton species are sensitive or tolerant to pollution, both in the form of organic and inorganic pollution, such as heavy metals, to describe the water health through the study of community structures (Arsad et al. 2019). Epiphytic periphyton was chosen as the object of this present research because epiphytic periphyton can be sampled more easily than epilithic periphyton (attached to bedrock). After all, the river is quite deep with the condition of the substrate, which tends to be muddy. Epiphyte's study is important to know their ecological importance and functions (Letakova et al. 2018). According to Pettit et al. (2016), epiphytic periphyton is one type of periphyton that lives attached to parts of water plants, both leaves, and stems. According to Saputra et al. (2018), using biological indicators, the advantages that can be gotten include reflecting the overall ecological quality, integrating different effects, and the provision of an accurate measurement of the effects of biological communities' environmental changes. 
Rivers are lotic waters that have currents flowing from upstream to downstream. A river is also a form of aquatic ecosystem that has a vital role as a living habitat for aquatic biota and the hydrological cycle, and it serves as a water catchment area for the surrounding area (Schofield et al. 2018; Melati et al. 2021). Rivers are widely used as sources of water for domestic activities, tourism, agriculture, and fisheries activities. According to Gunton et al. (2017), rivers provide benefits to communities around the river landscape, including urban areas, and their surroundings. Rivers provide a supply of water used to meet basic needs (for example, drinking) or meet economic needs (for example, industrial use of water). The Brantas River is one of the main rivers, the source of water for people in East Java (Hayati et al. 2017).

The existence of the Brantas River is crucial for the community because it is the largest supplier of raw water for the City of Surabaya and Malang. The Brantas River originates in Batu City and then flows through the cities of Malang, Blitar, Tulungagung, Kediri, Jombang, Mojokerto. The Brantas River, which passes through Blitar City, is used as water source to support people's lives and is also used as a conservation area for Bader Fish (Barbony balleroides), which are the typical fish of the Brantas River. Various community activities carried out on the Brantas River will lead to changes in water quality status, affecting water availability and affecting the survival and diversity of aquatic biota. Therefore, it is necessary to assess the condition of these waters. Based on these problems, this present research aims to analyze the epiphytic periphyton community structure and analyze the river health status using a saprobic index.

\section{MATERIALS AND METHODS}

\section{Research site}

This research was located on the Brantas River situated in the Omah Iwak Badher Bank Conservation Area, Tawangrejo Village, Binangun Sub-district, Blitar District, East Java, Indonesia. The research was conducted from January 6 to February 15, 2020 during the west monsoon. The climate condition in Java in this season is the rainy season. The highest peak of rainfall on the island of Java occurs during the west monsoon where the wind blows from Asia to Australia, delivering a lot of water vapor to form rain. The gust of wind will cause a flowing motion of a mass of water called currents. When the west monsoon occurs, the current also moves from the direction of the Asian continent to the Australian continent (Jourdain et al. 2013). The sampling points were determined using a purposive sampling method, where the sampling points were divided into three sites. First site is based on areas commonly used for fishing and other community activities, namely upper stream (Site 1, 8010'32.49' S-112²1'54.93" E), representing residential areas with domestic waste disposal. The second site is in the middle stream (Site 2, $8^{\circ} 10^{\prime} 9.84$ " S-112 21 '31.56" E), representing the core conservation zone. Therefore, the third site is the lower stream (Site 3, 809'59.928" S-112 $21^{\circ}$ '4.212" E) which represents agricultural and plantation areas as well as small river bifurcations (Figure 1). Sampling was carried out three times with two replications and two-week intervals. Measurement or calculation of samples was carried out in situ (temperature, current velocity, and $\mathrm{pH}$ ) and ex-situ (dissolved oxygen, ammonia, nitrate, orthophosphate, total organic matter, calculation of periphyton abundance, calculation of relative abundance, diversity index, uniformity index, dominance index, and saprobic index).

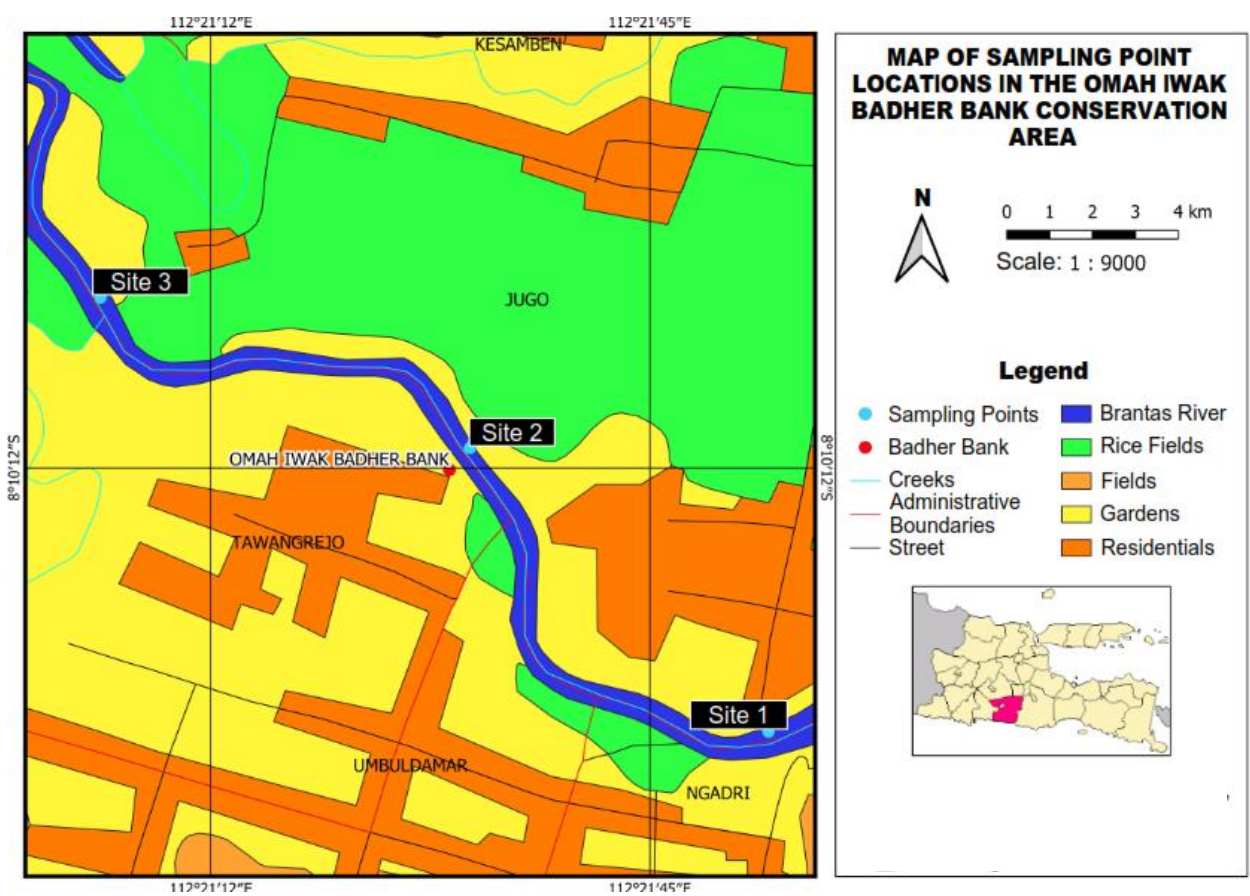

Figure 1. Map of Sampling Point Locations in the Omah Iwak Badher Bank Conservation Area (Research Documentation 2020) 


\section{Procedure}

Epiphytic microalgae sampling

Epiphytic microalgae samples were taken using the quadrant transect method, namely by selecting submerged plants (stems or leaves part) as the epiphytic colonized sampling site. According to Parker et al. (2018), the samples come from only one plant species, and the plants are not covered by sediment. This sampling of epiphytic microalgae was based on using the $5 \times 5 \mathrm{~cm}^{2}$ quadrant method for rooted plant samples. Epiphytic microalgae from each quadrant transect at each site were selected and taken randomly. This is to see the types of microalgae found in these parts of the plant as a representative of epiphytic microalgae that exist at a predetermined site. Epiphytic microalgae were separated from the plant surface by sweeping the substrate of the stems or leaves of the plants which were submerged in water, gently brushing them with a toothbrush, dousing them with distilled water, and putting them in a $10 \mathrm{~mL}$ pot jar to the brim and adding four drops of Lugol as a preservative for epiphytic microalgae samples (Saputra et al. 2018).

\section{Observation of periphyton samples (epiphytic microalgae)}

Observation of periphyton includes density calculations and types of periphyton using the Lackey Drop Micro transect Counting Method from APHA (2009) with the aid of a binocular microscope at 400x magnification. Afterward, it was followed by an analysis of the calculation of individual abundance (APHA 2012), relative abundance (Salahi et al. 2017), the diversity index (Sournia 1978), uniformity index (Sournia 1978), and dominance index (Ludwig and Reynolds 1988), with the following formula:

$$
\mathrm{K}=\frac{\mathrm{n} \times \mathrm{At} \times \mathrm{Vt}}{\operatorname{Ac} \times \mathrm{Vs} \times \mathrm{As}}
$$

Where, K: Periphyton abundance (Ind. $\mathrm{cm}^{-2}$ ); $\mathrm{n}$ : The number of periphyton observed (Ind); As: The area of the substrate scraped off $\left(\mathrm{mm}^{2}\right)$; At: Glass cover area $(20 \times 20$ $\left.\mathrm{mm}^{2}\right)$; Ac: Field of view $\left(\mathrm{mm}^{2}\right)$; Vt: Sample volume (10 $\mathrm{mL}$ ); Vs: the volume of concentrate in the observed glass object $(\mathrm{mL})$.

$$
\mathrm{KR}=\underline{\mathrm{ni}} \times 100 \%
$$

Where: KR: Relative abundance (\%); ni: the number of individuals in the genus (Ind); $\mathrm{N}$ : Total number of individuals found.

$$
\mathrm{H}^{\prime}=\mathrm{Pi} \log 2 \mathrm{pi}
$$

Where, H': Diversity index; Pi: ni/n; $\log 2$ pi: A constant based on the Shannon Waiver category table.

The diversity index value can be categorized: $\mathrm{H}^{\prime}<1=$ low diversity; $1<\mathrm{H}^{\prime}<3=$ moderate diversity; $\mathrm{H}^{\prime}>3=$ high diversity (Wilhm and Doris 1968).

\section{$\mathrm{E}=\mathrm{H} / \mathrm{Hmax}$}

Where, E: Uniformity index; H': Diversity index; $\mathrm{H}$ $\max =\log 2 \mathrm{~S} ; \mathrm{S}$ : Total number of individuals

$$
\mathrm{D}=(\mathrm{ni} / \mathrm{N})^{2}
$$

Where, D: Dominance index; N: Total number of individuals; ni: The number of individuals of the-ith species.

\section{Measurements of water quality parameters}

The measurements of supporting water quality parameters including temperature (Hg thermometer; APHA 2017), current velocity (Current Meter; APHA 2017) and pH (pH meter; APHA 2017) were carried out in situ. Meanwhile, the measurements of dissolved oxygen (DO) (Winkler method; APHA 2017), ammonia (spectrophotometer; APHA 2017), nitrate (spectrophotometer; Boyd 1979) orthophosphate (spectrophotometer; Boyd 1979), and total organic matter (titration method; APHA 2017) were carried out ex-situ. Moreover, the measurements of chemical physics parameters were done to support the data obtained concerning the epiphytic microalgae organisms found in the waters. Statistical analyses were used to determine the correlation of water quality parameters to the abundance of periphyton by using Principal Component Analyses (PCA) with software PAST.

\section{Data analysis}

Saprobic index calculation was used to determine the level of pollution of the Brantas River by using the formula from Drescher and Van Der Mark (1976):

$$
X=\frac{C+3 D-B-3 A}{A+B+C+D}
$$

Where, X: Saprobic index; A: Number of species from the polysaprobic saprobic group; B: Number of species from the saprobic $\alpha$-mesosaprobic group; $C$ : Number of species from the saprobic $\beta$-mesosaprobic group; $D$ : Number of species from the saprobic oligosaprobic group.

Polysaprobic: saprobic conditions where heavy pollution occurs, DO content is very little or almost nonexistent, bacterial population is dense, as well as $\mathrm{H}_{2} \mathrm{~S}$ content is high; $\alpha$-mesosaprobic: saprobic conditions where moderate to heavy pollution occurs, DO content starts to rise, bacterial density is relatively high, and $\mathrm{H}_{2} \mathrm{~S}$ is not existent; $\beta$-mesosaprobic: saprobic conditions where mild to moderate pollution occurs, DO content is high, bacterial density decreases, and nitrates are produced; Oligosaprobic: saprobic conditions where there is no pollution in the waters, DO content is high, and bacterial density is very low. 


\section{RESULTS AND DISCUSSION}

\section{Epiphytic microalgae community structure}

In this study, various types of epiphytic microalgae are obtained at the three sampling sites. The epiphytic microalgae found come from six divisions with 59 different genera. The six divisions found are Bacillariophyta (43\%), Chlorophyta (26.3\%), Cyanophyta (16.7\%), Charophyta (8\%), Ochrophyta (5\%), and Rhodophyta (1\%). The most identified genus is from the Bacillariophyta Division with 28 genera. The least identified genus is from the Rhodophyta division with only one genus. Meanwhile, the Cyanophyta division has eight genera, the Chlorophyta division has eight genera, the Charophyta division has ten genera, and the Ochrophyta division has four genera.

Based on the observation, the density value of the periphyton sample from the Brantas River, Tawangrejo Village at site in week 1 was of 257,975 cells. $\mathrm{cm}^{-2}$, week 2 was of 971,199 cells. $\mathrm{cm}^{-2}$, and week 3 was of 242,800 cells. $\mathrm{cm}^{-2}$. Meanwhile, at site 2 the result obtained in week 1 was 576,649 cells. $\mathrm{cm}^{-2}$, week 2 was 1,229,174 cells. cm ${ }^{2}$, and week 3 was 303,500 cells. $\mathrm{cm}^{-2}$. Furthermore, at site 3 the result obtained in week 1 was 804,274 cells. $\mathrm{cm}^{-2}$, week 2 was 1,168,474 cells. $\mathrm{cm}^{-2}$, and week 3 was 804,274 cells. $\mathrm{cm}^{-2}$.

The relative abundance of identified periphyton at site 1 was the Bacillariophyta division (60\%), the Cyanophyta division (11\%), the Chlorophyta division (12\%), the Charophyta division (8\%), the Ochrophyta division (5\%), and the Rhodophyta division (3\%). Furthermore, the relative abundance of identified periphyton at site 2 was Bacillariophyta division (57\%), the Cyanophyta division (19\%), the Chlorophyta division (5\%), the Charophyta division (10\%), and the Ochrophyta division (9\%). Lastly, the relative abundance of identified periphyton at site 3 was the Bacillariophyta division (12\%), the Cyanophyta division (20\%), the Chlorophyta division (62\%), the Charophyta division (6\%), and the Ochrophyta division $(1 \%)$. The relative abundance of epiphytic microalgae is presented in Figure 2.
The periphyton division of Bacillariophyta is the type most commonly found in this study. Bacillariophyceae is cosmopolitan. The Bacillariophyta Division is a microalga with mucus, so it has an excellent ability to attach to fastflowing river substrates. The Bacillariophyta Division has an adherent device to attach to the substrate in a gelatine stalk with high adhesion (Guan et al. 2021). Bacillariophyta is a group of autotrophic epiphytic microalgae, the most abundant of which are found in freshwater, brackish water, and marine water worldwide and moist terrestrial habitats (Al Diana et al. 2020). Bacillariophyta accounts for $20 \%$ of global photosynthetic carbon fixation. Most of the 100,000 species of Bacillariophyta estimated to live attached to the surface or on the sediment use unique organelles called the raphe system (Mann 2016). The second-highest relative abundance, Chlorophyta, can be found in almost every environment from arctic regions to deserts. Chlorophyta plays an important role in the global carbon, nitrogen and phosphorus cycle. This group of microalgae has a high tolerance for weather conditions (Woo Jo et al. 2020).

Cyanophyta, a group of photosynthetic organisms found in various aquatic environments, is found in this study. The photosynthetic pigments of Cyanophyta give a different color, generally known to be turquoise (Sari et al. 2019a). Some of these Cyanophyta groups have nitrogen-fixing potential, making them important for waters (Nuhu 2013; Sari et al. 2019b). In the Brantas River is also found the Ochrophyta group, yet their relative abundance is low. Ochrophyta is a group of organisms found in almost all aquatic environments. The heterokonts possessed by this group of microalgae are the most diverse. Ochrophyta has photosynthetic pigments, namely chlorophyll a, c and fucoxanthin. Haptophytes are also found which give a golden brown or brownish-green color (Harper et al. 2012). On the other hand, the Rhodophyta classes mostly live in marine waters, especially in the deep parts. There are very few Rhodophyta classes in freshwater, and some also livein groundwater (Arsad et al. 2019). According to Heimann and Huerlimann (2015), the Rhodophyta division is a unicellular species, containing phycocyanin and phycoerythrin, which can be found in the sea and freshwater. However, in freshwater, this group is rarely found.

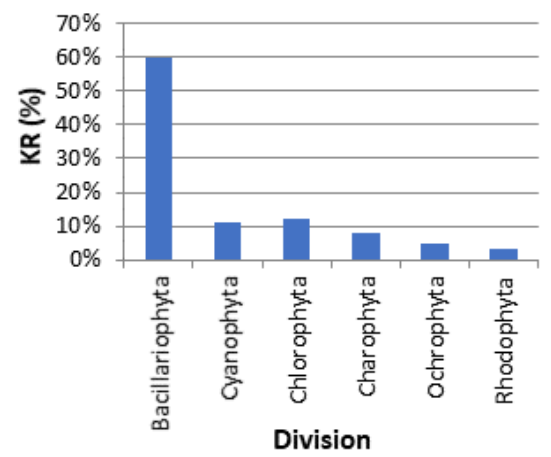

A

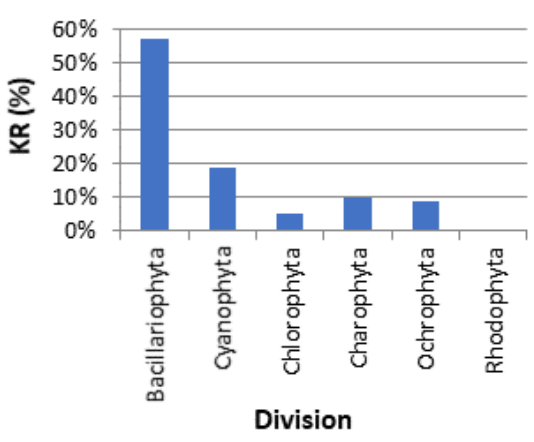

B

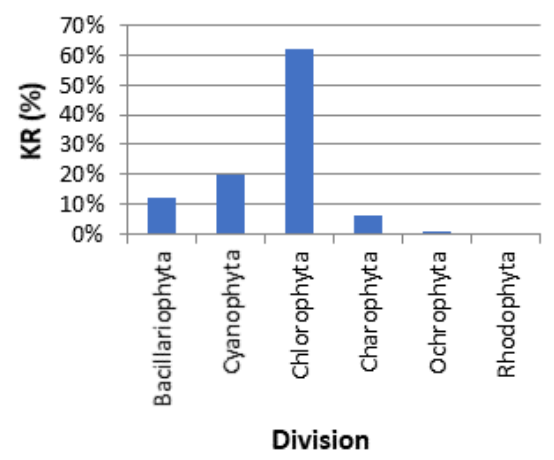

C

Figure 2. Relative abundance (KR) of epiphytic microalgae. A. Site 1; B. Site 2; and C. Site 3 


\section{Quality index}

Diversity index measurement can be used as an indicator of the status of the ecological system and indicate habitat characteristics. Diversity depends on the ecological role, namely competition, predation, and succession (Valiente-Banuet et al. 2015). Diversity is a condition that shows the number of different individuals in an ecosystem compared to the total of all individuals in the ecosystem (Herawati et al. 2019). Changes in the diversity index value reflect the impact of environmental changes on aquatic ecosystems (Ye et al. 2017).

Uniformity is the distribution of different genera, and it is obtained from the diversity relationship. A high uniformity index value indicates an even distribution of individuals, and each genus has the same opportunity to utilize nutrients available in the waters (Melsasail et al. 2018). According to Krebs (1989), the uniformity value (E) is close to 0 , so the uniformity value is getting smaller or lower in a population. If the value of $\mathrm{E}$ is close to 1 , it will show uniformity, which means that the community has relatively uneven species. The main factors that affect species uniformity and dominance include the destruction of natural habitats such as conversion of land to other uses, chemical and organic pollution, and climate change (Suyorno and Sudarso 2019).

Dominance index measurement is done to determine whether a particular species dominates or not in certain waters (Hossain et al. 2017). Aquatic ecosystems will experience damage due to the presence of certain epiphytic microalgae species that experience an increase and begin to dominate the ecosystem gradually replacing other species. On the other hand, in aquatic ecosystems that have good ecology, there is no dominant epiphytic microalgae species, so the ecosystem is balanced and the number of certain species is small, thereby reducing the dominance index. A low dominance index value indicates that the aquatic ecosystem is in good condition (Martsenyuk et al. 2016). According to Krebs (1989), the dominance value (D) ranges from 0 to 1 , meaning that if the $\mathrm{D}$ value is closer to 1 , the role or dominance of a species in one community is higher, whereas if the dominance value (D) approaches 0 then there is no species that dominate others.

\section{Diversity index}

The results of the diversity index $\left(\mathrm{H}^{\prime}\right)$ of epiphytic microalgae obtained at all sites range from 1.212-2.617 with the value in site 1 ranging from 1.952-1.487; site 2 ranging from 1.474-2.617; and site 3 ranging from 1.2121.630 (Table 1). The data were fluctuated because of several factors such as physicochemical factors that influenced the availability of species. Concerning the diversity category, according to Wilhm and Dorris (2007) Shannon Weiner diversity index $\mathrm{H}^{\prime}=<1$ is classified as heavily polluted; $\mathrm{H}$ '= $1-3$ is classified as moderately polluted and $\mathrm{H}^{\prime} \Rightarrow 3$ is classified as clean waters. According to Perwira and Ulinuha (2014), low diversity levels in waters indicate low productivity and high pressure on ecological conditions that cause an unstable ecosystem or an unhealthy environment.

It can be concluded that the diversity index value obtained in the Brantas River is included in the moderate diversity group, which means that it shows moderate ecology, moderate productivity, and less stable ecological pressure or an unhealthy (moderately polluted) aquatic environment.

\section{Uniformity index}

The results of the uniformity index (E) obtained for all sites range from 0.307-2.151 with the value in site 1 ranging from 0.907 to 1.378 ; site 2 ranging from 0.773 to 1.512; and site 3 ranging from 0.307 to 2.151 (Table 1). According to Ulfah et al. (2019), a high uniformity value can be related to a high diversity index while the dominance index value is low. Heinrichs et al. (2020) argue that waters with high organism uniformity mean that the waters are in a balanced state where no competition occurs for both food and living habitat. According to Nashaat (2019), a low uniformity index indicates that there is dominance of several species with high density due to environmental pressures. Meanwhile, a higher uniformity index value indicates the same abundance of each species and no dominance of species.

Based on the results of the study, the uniformity value obtained at all stations can be classified as high uniformity because the average value exceeds one (1) which indicates that the epiphytic microalgae in the waters are evenly distributed in the number of individuals.

\section{Dominance index}

The results of the calculation of the dominance index (D) at all sites get values ranging from 0.105-0.549 with the value in site 1 ranging from 0.229 to 0.275 ; site 2 ranging from 0.105 to 0.408 ; and site 3 ranging from $0.140-2.549$ (Table 1). A low dominance index value is good for waters because no organisms dominate in one area. According to Sihombing et al. (2017), the dominance index value which is close to 0 means that there is no type of organism that dominates in these waters and the distribution of the types of organisms is more even, whereas if the dominance index value is close to 1 then dominance occurs by one type of organism in the waters.

Table 1. Diversity index, uniformity index, and dominance index

\begin{tabular}{cccccccccc}
\hline \multirow{2}{*}{ Site } & \multicolumn{3}{c}{ Diversity Index $\left(\mathbf{H}^{\prime}\right)$} & \multicolumn{3}{c}{ Uniformity Index $(\mathbf{E})$} & \multicolumn{3}{c}{ Dominance Index (D) } \\
\cline { 2 - 10 } & W1 & W2 & W3 & W1 & W2 & W3 & W1 & W2 & W3 \\
\hline 1 & 1.855 & 2.617 & 1.630 & 0.962 & 1.512 & 0.700 & 0.253 & 0.105 & 0.219 \\
2 & 1.952 & 2.362 & 2.272 & 1.378 & 0.773 & 2.151 & 0.229 & 0.121 & 0.140 \\
3 & 1.487 & 1.474 & 1.212 & 0.907 & 1.048 & 0.307 & 0.275 & 0.408 & 0.549 \\
\hline
\end{tabular}

Note: W: week 
The increase in the value of the dominance index impacts to the decrease in the diversity index. High dominance values indicate the distribution of the same species. The presence of dominant species is influenced by ammonia, phosphate, nitrate, nitrite, $\mathrm{pH}$, and Dissolved Oxygen (Kostryukova et al. 2018).

It can be concluded that the dominance index value of all sites is included in the low to moderate dominance category, which indicates that no epiphytic microalgae species dominate on the Brantas River and the aquatic ecosystem is in good condition.

\section{Saprobic index}

Saprobic index is a value used to detect water pollution from organic matter. Saprobic describes water quality in relation to the content of organic matter and the composition of organisms in waters. In the saprobic index measurement, an organism acts as a bioindicator (Suryani et al. 2018). The saprobic index is an index that is closely related to the level of pollution and can be determined after knowing the structure of the microalgae community in the waters (Hariyati and Putro 2019). Based on the results of this present research, the saprobic index at all observation sites has a value ranging from- 0.18 to 0.55 (Figure 3 ).

The saprobic index value at site 1 is $\beta / \alpha$-mesosaprobic ( 0.0 to 0.5$)$; site 2 is $\beta$-mesosaprobik ( 0.5 to 1.0$)$; site 3 is $\alpha / \beta$-mesosaprobik ( -0.5 to 0.0$)$. This value indicates that the river waters experience mild to moderate levels of pollution by organic and inorganic materials (Radwan et al. 2017). It can be concluded that the saprobic index value of all observed samples is included in the $\alpha / \beta$-mesosaprobic to $\beta$ mesosaprobic saprobic level with mild to moderate pollution levels by organic and inorganic materials.

Based on Figure 3, it can be seen that the saprobic level of all sites tends to decrease from the first week to the third week. It can be said that the condition of the Brantas River in Tawangrejo Village is getting worse at downstream. Site 3 has the lowest saprobic index value compared to the other 2 sites due to the high input of waste from small river bifurcations that carry organic or inorganic materials resulting from industrial and domestic industrial activities.

The saprobic index value of the $\beta$-mesosaprobic category shows that there is little pollution that enters the waters from both organic and inorganic materials. The activities of rice fields or aquaculture, in general, will contribute nutrients from the use of fertilizers that enter the waters. Microorganisms will decompose the fertilizers into inorganic materials that can trigger the growth and development of photoautotrophic organisms such as periphyton and phytoplankton. The low saprobic value might occur to the large number of industrial and household activities that utilize the watershed (Sari et al 2019b). At site 3, a branch of a tributary is suspected of carrying waste from industrial and domestic activities, so visually, the river water looks cloudy and slimy at the riverside (Radwan et al. 2017).

\section{Supporting water quality parameters}

Analysis of water quality parameters affecting periphyton communities consisting of temperature, current velocity, $\mathrm{pH}$, dissolved oxygen (DO), ammonia $\left(\mathrm{NH}_{3}\right)$, nitrate $\left(\mathrm{NO}_{3}{ }^{-}\right)$, orthophosphate, and total organic matter (TOM) (Table 2). The value of the average water quality parameter is still at a good quality standard level for periphyton growth, but the ammonia and TOM parameters have a value that exceeds the quality standard at a certain time. Ammonia and TOM levels in the waters that exceed the quality standard are thought to come from agricultural activities, domestic waste and industrial waste around the location.

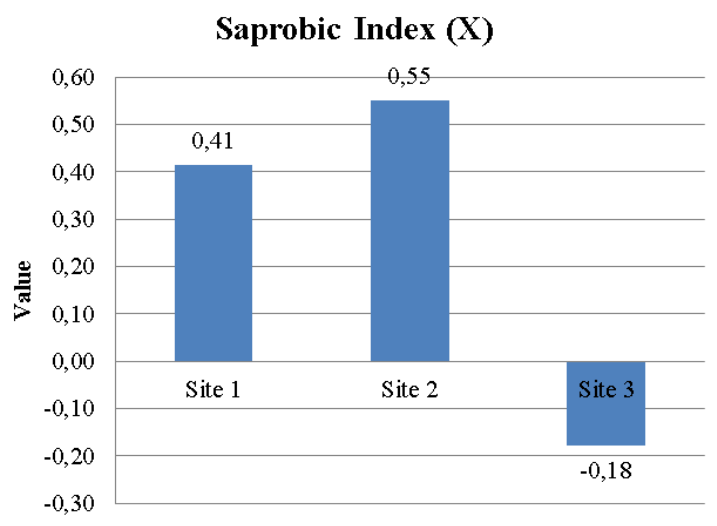

Figure 3. Graph of saprobic index value

Table 2. Water quality observation data

\begin{tabular}{|c|c|c|c|c|c|}
\hline Parameter & Unit & Site 1 & Site 2 & Site 3 & Literature \\
\hline Temperature & ${ }^{\circ} \mathrm{C}$ & $27.5-29.5$ & $25.5-30.0$ & $26.5-28.5$ & $20-30^{\circ} \mathrm{C}$ (Martins et al. 2018) \\
\hline Current velocity & m. $\mathrm{s}^{-1}$ & $0.69-1.17$ & $0.55-0.85$ & $0.44-0.78$ & $\begin{array}{l}\text { Fast current } 0.5-1 \mathrm{~m}^{-1} \mathrm{~s}^{-1} \text { to moderate current } \\
0.25-0.5 \mathrm{~m} . \mathrm{s}^{-1} \text { (Mason 1981) }\end{array}$ \\
\hline $\mathrm{pH}$ & & $6.86-7.42$ & $6.76-7.45$ & $7.02-7.31$ & 6.8-8.5 (Pacheco et al. 2015) \\
\hline DO & $\mathrm{mg} \cdot \mathrm{L}^{-1}$ & $5.00-6.26$ & $5.12-6.41$ & $5.15-6.45$ & $5.0 \mathrm{mg} . \mathrm{L}^{-1}$ (Herawati et al. 2019) \\
\hline Ammonia & mg. $\mathrm{L}^{-1}$ & $0.038-0.134$ & $0.033-0.410$ & $0.04-0.345$ & $<0.02 \mathrm{mg} . \mathrm{L}^{-1}$ (Bintoro and Apriyadi 2016) \\
\hline Nitrate & $\mathrm{mg} . \mathrm{L}^{-1}$ & $0.211-0.387$ & $0.085-0.655$ & $0.121-0.375$ & Oligotrophic (Adriani et al. 2019) \\
\hline Orthophosphate & mg. $\mathrm{L}^{-1}$ & $0.074-0.127$ & $0.050-0.116$ & $0.040-0.085$ & Mesotrophic (Sevindik et al. 2015) \\
\hline TOM & mg. $\mathrm{L}^{-1}$ & $6.95-39.82$ & $7.58-68.26$ & $7.58-115.02$ & $<10 \mathrm{mg} . \mathrm{L}^{-1}=$ clean $($ Nursyam 2017$)$ \\
\hline
\end{tabular}


According to Hibban et al. (2016), the presence of ammonia that exceeds the threshold level in the waters indicates the starting point of pollution which the presence of pungent smell can indicate. This ammonia compound can come from the input of domestic, industrial and agricultural waste. According to Dianto et al. (2020), the high TOM is caused by high human activities. Sources of total organic matter in the water can come from household and agricultural waste. This is in accordance with the sampling in this study, site 1 is located in residential areas with domestic waste disposal and site 3 where belongs to agricultural and plantation areas.

According to Wersal and Madsen (2013), the temperature in rivers is influenced by light intensity. The higher the intensity of sunlight, the higher the temperature of the waters. Besides, it is influenced by the vegetation in the riverbanks. The more vegetation on the riverbanks, the more humid the temperature. This is because the vegetation acts as a stabilizer for temperature and humidity. The temperature in the Brantas River can also be tolerated by epiphytic microalgae, with the optimal temperature for living periphyton of $27-31^{\circ} \mathrm{C}$ (Pratama et al. 2017). Current velocity is influenced by wind and the substrate in the form of mud, sand, or rock. The fast current velocity can reduce the types of organisms that live (epiphytic microalgae), so only certain types can survive against the current. The existence of Bacillariophyta is a division capable of growing in the range of fast to slow currents (Whitton 1975).

The $\mathrm{pH}$ obtained in the study is 6.76-7.45. An increase in acidity is influenced by organic and inorganic waste disposed of into the river (Ayilara et al. 2020). The decomposition activity of organic matter influences low dissolved oxygen. Waste disposal in water can reduce dissolved oxygen content (Boudaghpour 2011). The increase in dissolved oxygen is also due to the supply of oxygen from the photosynthesis and diffusion processes (Leidonald et al. 2019). The source of ammonia in rivers is the reduction of nitrogen gas from the diffusion process of atmospheric air, industrial waste and domestic waste (Cho et al. 2019). Ammonia can influence the differences in the epiphytic microalgae that dominate in each water (Trias et al. 2011). According to Xue et al. (2016), pollution can come from fertilization, animal waste and human waste causing high nitrates in rivers or lakes. Nitrate content in waters can affect Periphyton biomass in waters (Pratama et al. 2017). The high content of orthophosphate in waters can occur due to household waste from residential areas in the form of detergents. Detergents can increase the concentration of orthophosphate because this ion is one of the constituent compositions (Tungka et al. 2017). A good orthophosphate range value for periphyton growth is 0.09 $1.8 \mathrm{mg}$. L ${ }^{-1}$ (Putrianti et al. 2015). The high TOM content in the water is suspected to be due to household waste around the river. This high TOM will affect dissolved oxygen levels in the waters and reduce the $\mathrm{pH}$ value in the waters (Nursyam 2017).

The analysis of PCA was calculated to present the relation of water quality parameters to periphyton abundance (Figure 4). The PCA analysis that has been carried out resulted in 2 main components, namely PC1 and PC2, representing $45.6 \%$ and $30.364 \%$, respectively of the total diversity of the analyzed variables. The result shows that Periphyton has a strong positive correlation with dissolved oxygen (DO). However, the periphyton has a negative correlation with TOM and current.

Research conducted at the Brantas River, Tawangrejo Village, using epiphytic microalgae bioindicators indicates the level of pollution is classified as mild to moderate. Nevertheless, there are recommendations that can be made for river management as an effort to prevent pollution, namely, improving land rehabilitation in the watershed, dredging sediment, clearing and arranging the riparian zone, and rearranging waste management sites (TPS) in the riparian zone.

The following are epiphytic microalgae found in research (Figure 5) with a microscope (400x magnification).

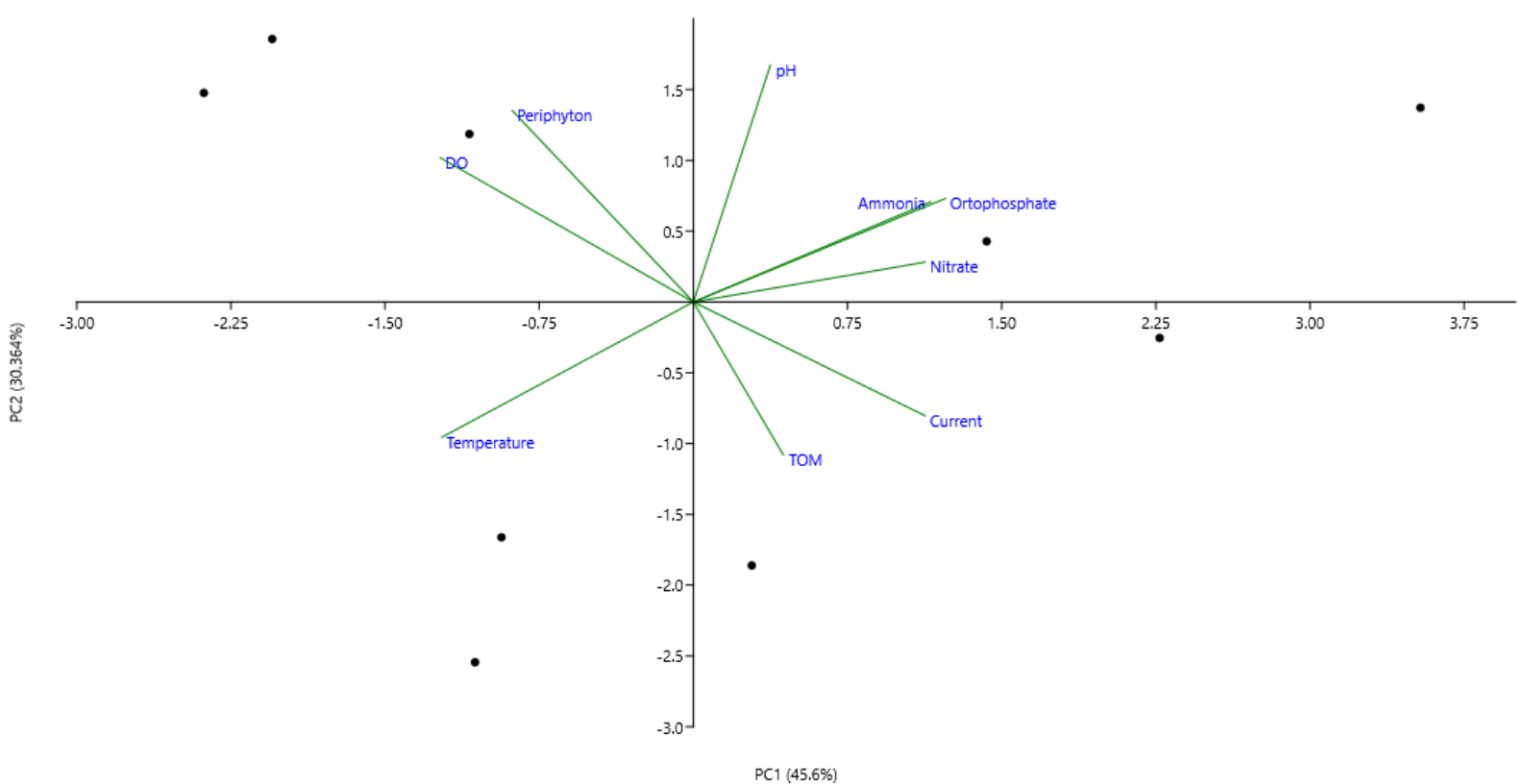

Figure 4. Biplot ordination of Principal Component Analyses (PCA) 

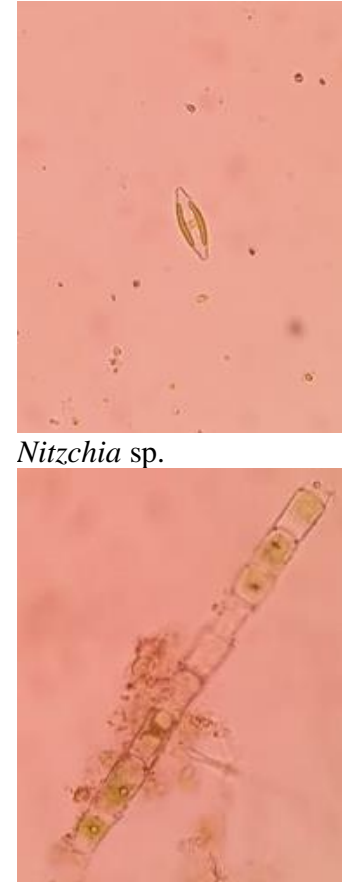

\section{Hyalotheca sp.}

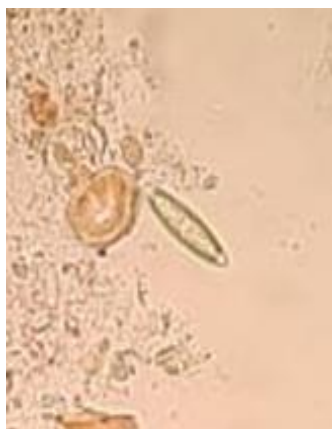

\section{Surirella sp.}

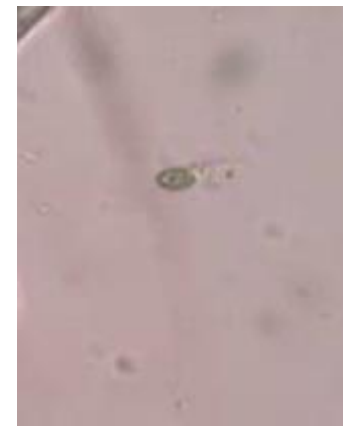

\section{Navicula sp.}

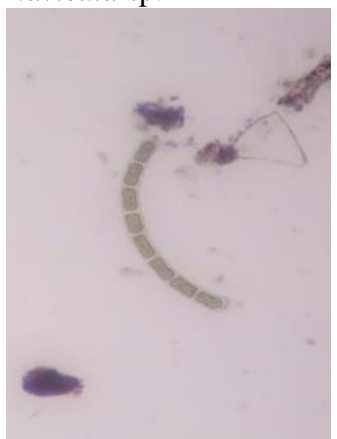

Sirogonium sp.

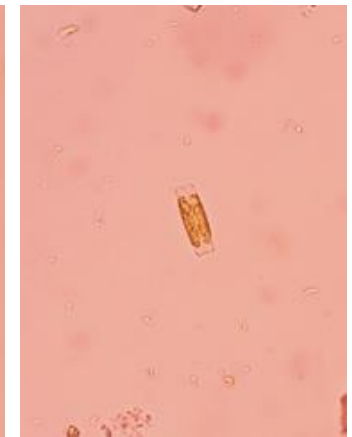

Mastogloia sp.

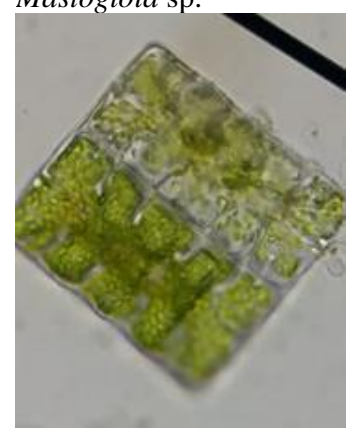

Micrasterias sp.

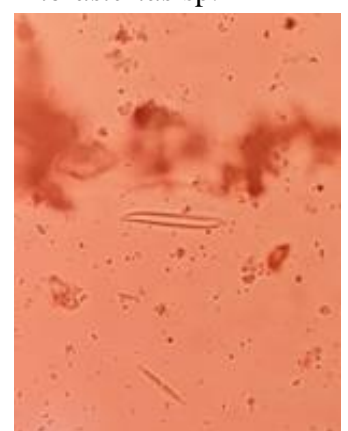

Coloneis sp.

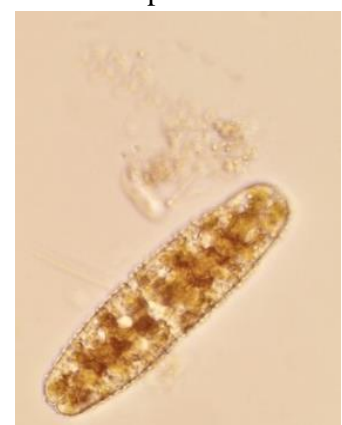

Tetmemorus sp.

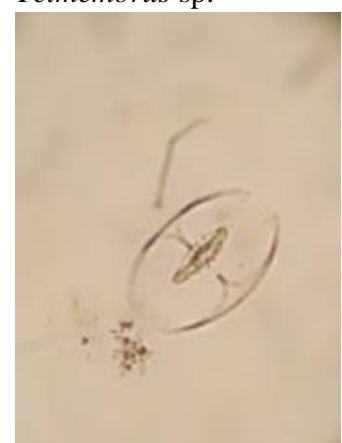

Amphiphora sp.

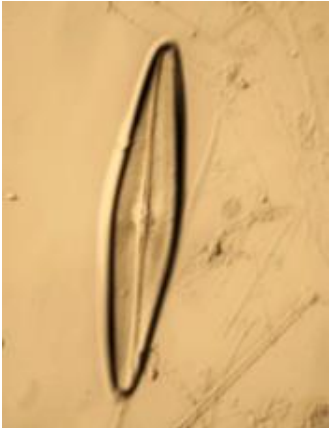

Scoliopleura sp.

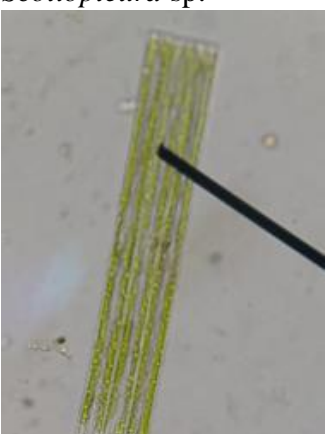

Fragillaria sp.

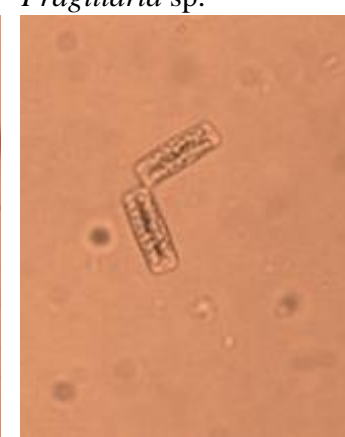

Diatoma sp.

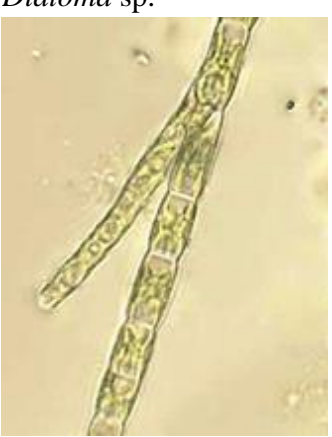

Chaetophora sp.

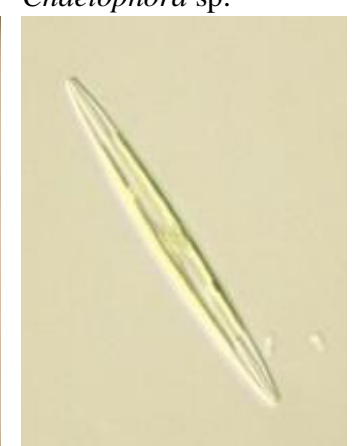

Amphipleura sp.

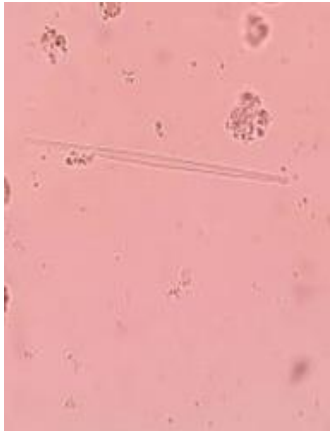

Synedra sp.

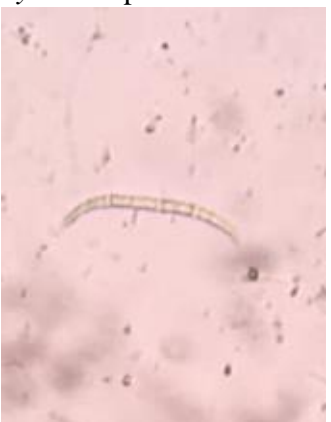

Closterium sp.

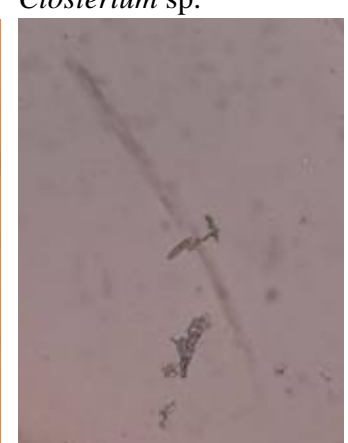

Diatomella sp.

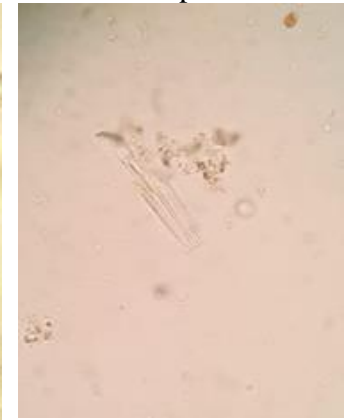

Tabellaria sp.

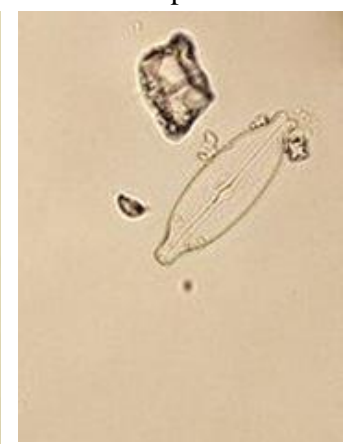

Anomoeoneis sp

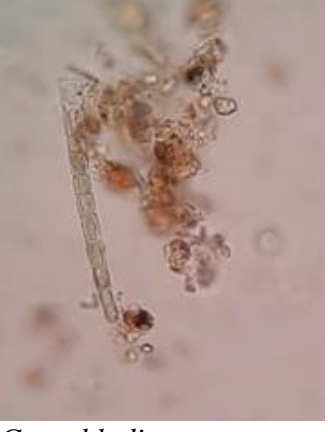

Groenbladia sp.

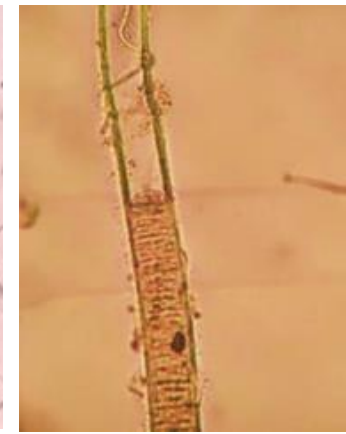

Lyngbya sp.

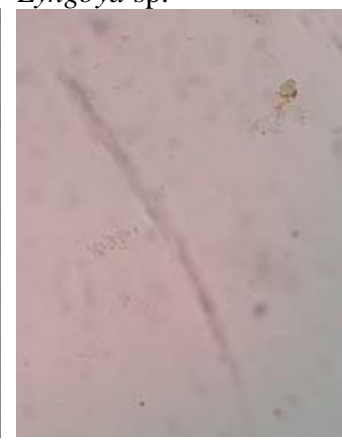

Melosira sp.

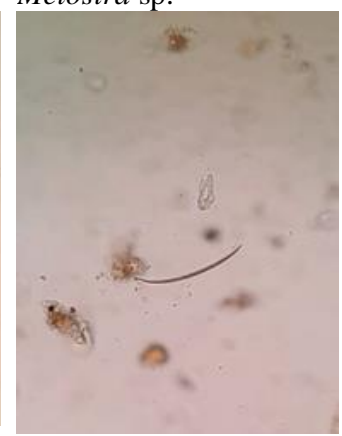

Dactylococcopsis sp.

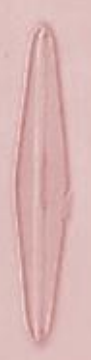

Brebissonia sp 

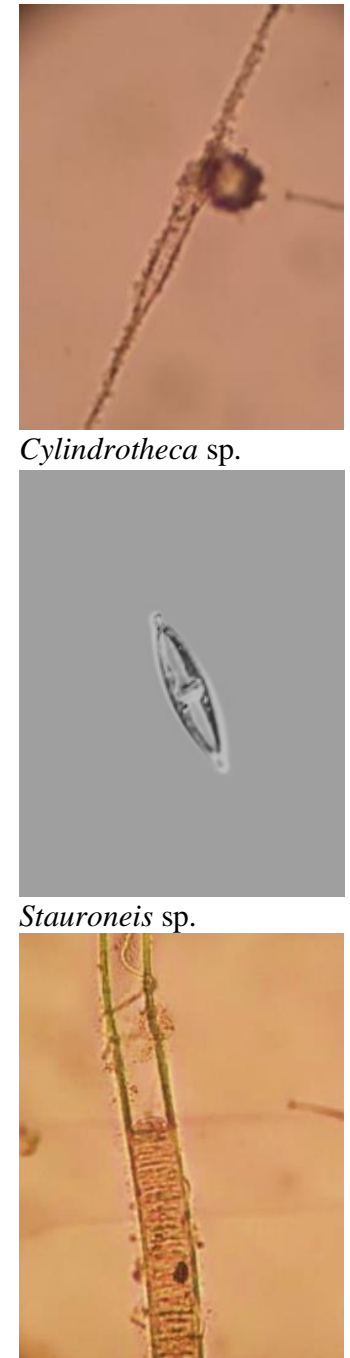

Lyngbya sp.

Striatella sp.

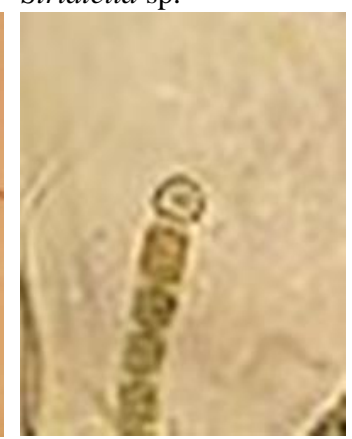

Microchaete sp.

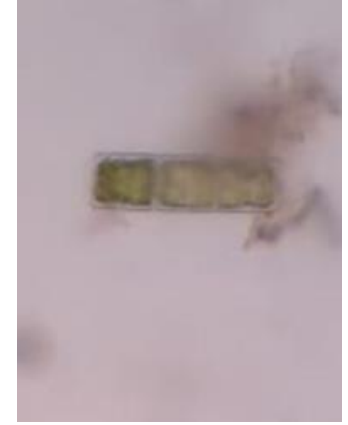

Microspora sp.

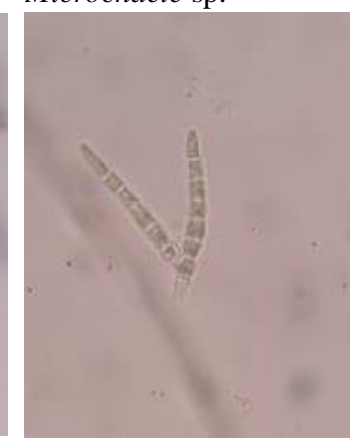

Microthomnion sp.

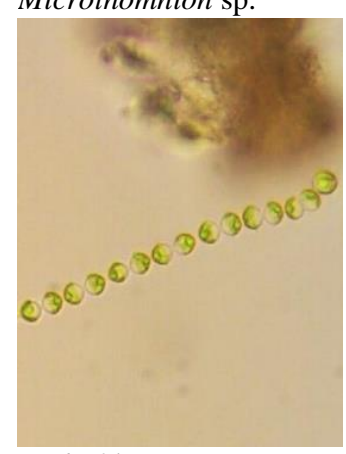

Radiofilum sp.

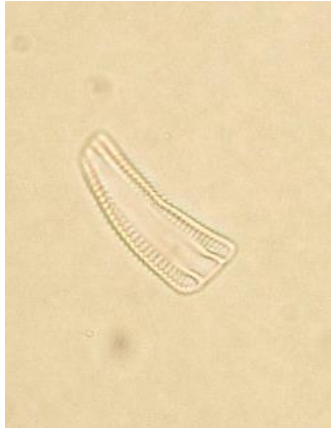

Rhoicosphenia sp.

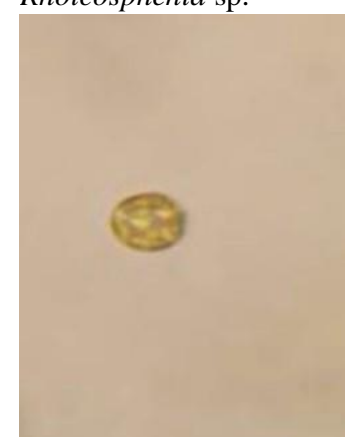

Thalassiothrix sp.

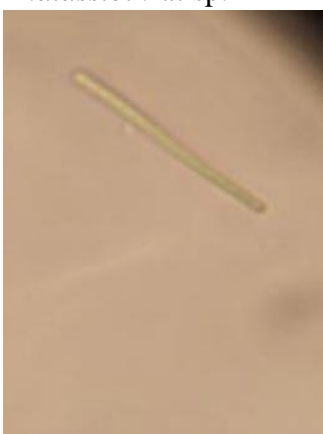

Oscillatoria sp.

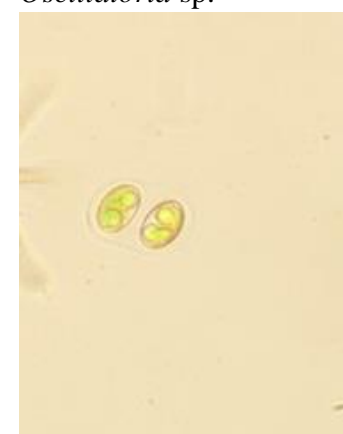

Oocystis sp.

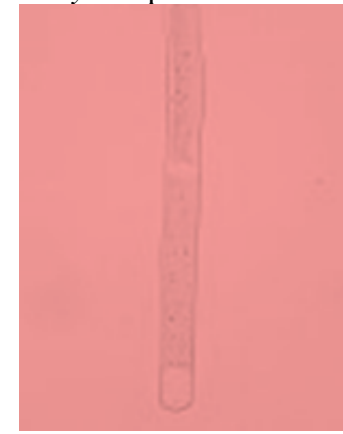

Gonatozygon sp.

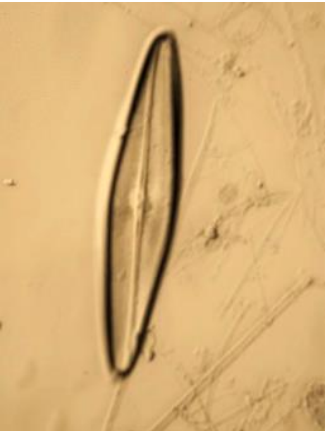

Scoliopleura sp.

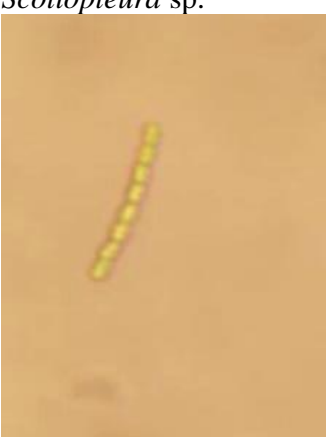

Anabaena sp.

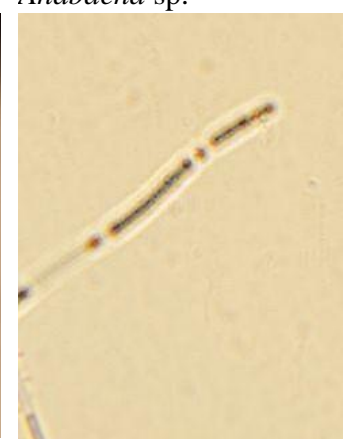

Symploca $\mathrm{sp.}$

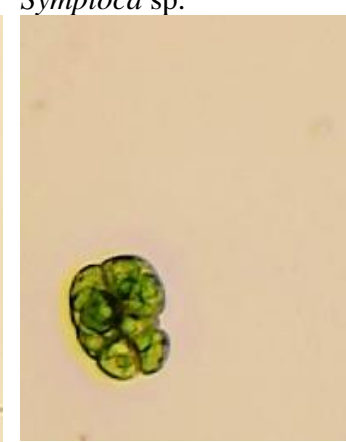

Pandorina sp.

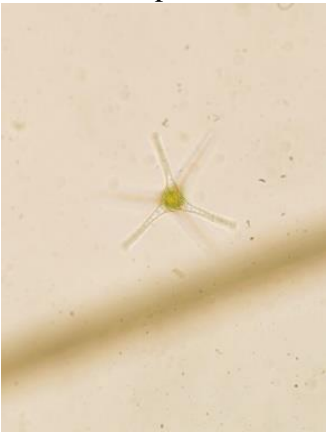

Staurastrum sp.

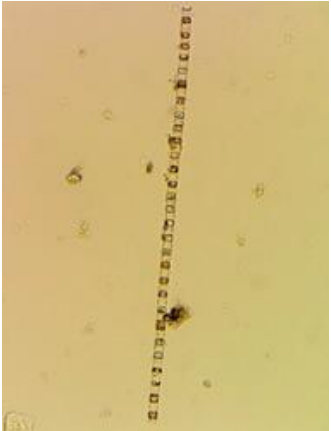

Skeletonema sp.

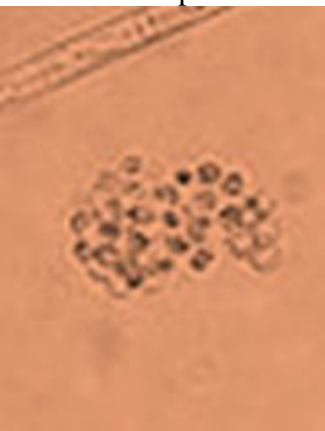

Gomphocphaeria sp.

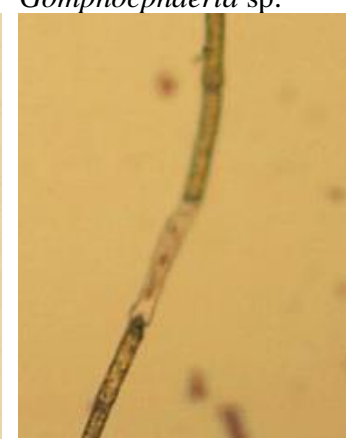

Cladhopora sp

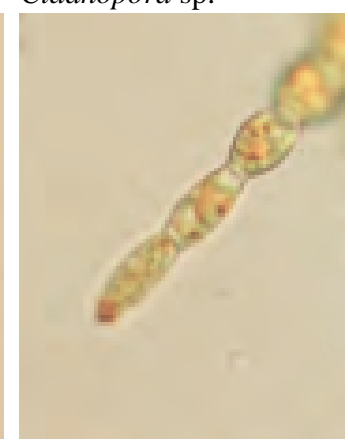

Phycopelis sp.

Figure 5. Epiphytic microalgae found in Brantas river, East Java, Indonesia 


\section{REFERENCES}

Adriani A, Ain C, Febrianto S. 2019. Konsentrasi nitrat fosfat di sungai banjir kanal barat dan sungai silandak Semarang concentration of nitrates phosphates in the banjir kanal barat and silandak rivers in Semarang. J Manag Aquat Resour 8 (4): 316-320. DOI: 10.14710/marj.v8i4.26550. [Indonesian]

Al Diana NZ, Sari LA, Arsad S, Pursetyo KT, Cahyoko Y. 2021. Monitoring of phytoplankton abundance and chlorophyll-a content in the Estuary of Banjar Kemuning River, Sidoarjo District, East Java. J Ecol Eng 22 (1): 29-35. DOI: 10.12911/22998993/128877.

American Public Health Association (APHA). 2009. Standard Method fo The Examination of Water and Wastewater. $22^{\text {th }}$ ed. American Public Health Association, Washington DC.

American Public Health Association (APHA). 2012. Standard Methods for The Examination of Water and Wastewater $22^{\text {nd }}$ edition. United Book Press Inc, Maryland.

American Public Health Association (APHA). 2017. Standard Methods for the Examination of Water and Wastewater. 23 $3^{\text {th }}$ ed. American Public Health Association, Washington DC

Arsad S, Zsalzsabil NAN, Prasetiya FS, Safitri I, Saputra DK, Musa M. 2019. Komunitas mikroalga perifiton pada substrat berbeda dan perannya sebagai biondikator perairan. Saintek Perikanan 15 (1): $73-$ 79. DOI: 10.14710/ijfst.15.1.73-79. [Indonesian]

Ayilara MS, Olanrewaju OS, Babalola OO, Odeyemi O. 2020. Water management through composting: challenges and potential. Sustainability 12 (4456): 1-23. DOI: $10.3390 /$ su12114456.

Bintoro A dan Apriyadi A. 2016. Pengukuran kadar amonia di Sungai Kumbe, Kabupaten Merauke, Provinsi Papua. Buletin Teknik Litkayasa Sumber Daya dan Penangkapan 14 (2): 135-140. [Indonesian]

Boudaghpour S. 2011. The effect of pollutants dissolved oxygen and temperature change (Case study Ghewel-Ozen river). J Water Sci Res 3 (1): 27-35.

Boyd CE. 1979. Water Quality in Ponds for Aquaculture. Birmingham Publishing, Alabama.

Cho S, Kambey C, Nguyen VK. 2019. Performance of anammox processes for wastewater treatment: A critical review on effects of operational conditions and environmental stresses. Water 12 (20): 1 30. DOI: $10.3390 / \mathrm{w} 12010020$

Dianto A, Ridwansyah I, Subeh L. 2020. Organic matter and organic carbon levels in sediment of Lake Maninjau West Sumatra. IOP Con Ser: Earth Environ Sci 535: 012030. DOI: 10.1088/1755 1315/535/1/012030.

Dresscher and Mark VD. 1976. A simplified method for the biological assessment of the quality of fresh and slightly brackish water. J Hydrobiol 48 (3):199-201.

Guan Y, Chen R, Sun G, Liu Q, Yu J, Lin C, Wang J. 2021. Secretion mechanism and adhesive mechanism of diatoms: Direct evidence from the quantitative analysis. Micron 140: 102951. DOI: 10.1016/j.micron.2020.102951.

Gunton RM, Asperen EN, Basden A, Bookless D, Araya Y, Hanson DR Goddard MA, Otieno G, Jones GO. Beyond ecosystem services: Valuing the invaluable. 2017. Trends Ecol Evol 32 (4): 249-257. DOI: $10.1016 /$ j.tree.2017.01.002.

Hariyati R, Putro SP. 2019. Bioindicator for environmental water quality based on saprobic and diversity indices of planktonic microalgae: A study case at Rawapening Lake, Semarang District, Central Java, Indonesia. J Phys: IOP Conf Ser 1217: 012130. DOI: 10.1088/17426596/1217/1/012130

Harper MA, Cooper VC, Chang FH, Nelson WA, Broady PA. 2012. Phylum Ochrophyta: brown and golden-brown algae, diatoms, silicioflagellates, and kin. In: Gordon DP (eds). New Zealand Inventory of Biodiversity 3:114-163. Canterbury University Press, Christchurch, New Zealand.

Hayati A, Tiantono N, Mirza MF, Putra IDS, Abdizen MM, Seta AR, Solikha BM, Fu'adil MH, Putranto TWC, Affandi M, Rosmanida. 2017. Water quality and fish diversity in the Brantas River, East Java Indonesia. J Biol Res 22 (2): 43-49. DOI 10.23869/bphjbr.22.2.20172.

Heimann K, Huerlimann R. 2015. Microalgal classification: Major classes and genera of commercial microalgal species. In: Kim S-K (eds). Handbook of Marine Microalgae. Academic Press, NY, USA.
Henrichs ME, Mori C, Dlugosh L. 2020. Complex interactions between aquatic organisms and their chemical environment elucidated from different perspectives. Youmares 9: 279-297.

Herawati H, Nurruhwati I, Dhahiyat Y. 2019. The structure of phytoplankton community to estimated trophic level in Jatigede reservoirs. Intl J Fish Aquat Res 4 (3): 33-37.

Hibban M, Rezagama A, Purwonto. 2016. Studi penurunan konsentrasi amonia dalam limbah cair domestik dengan teknologi biofiter aerobmedia turbular plastik pada awal pengolahan. Jurnal Teknik Lingkungan. 5 (2): 1-9. [Indonesian]

Hossain MRA, Pramanik MMH, Hasan MM. 2017. Diversity indices of plankton communities in the river meghna of Bangladesh. Intl J Fish Aquat Stud 5 (3): 330-334. DOI:10.4172/2157-7625.1000197.

Hutami WW, Sari LA, Masithah ED, Sahidu AM, Pursetyo KT. 2020. Effect of water quality on community structure of bivalve at Segoro Tambak Estuary, Sidoarjo, East Java, Indonesia. Asian J Water, Environ Pollut 17 (3): 81-86. DOI: 10.3233/ajw200041.

Jo SW, Do JM, Kang NS, Park JM, Lee JH, Kim HS, Yoon HS. 2020. Isolation, identification, and biochemical characteristics of a coldtolerant chlorella vulgaris knua007 isolated from King George Island, Antarctica. J Mar Sci Eng 8 (11): 935. DOI: 10.3390/jmse8110935.

Jourdain CN, Gupta AS, Taschetto AS, Ummenhofer CC, Moise AF, Ashok K. 2013. The Indo-Australian monsoon and its relationship to ENSO and IOD in reanalysis data and the CMIP3/CMIP5 simulations. Clim Dyn 41: 3073-3102. DOI: 10.1007/s00382-0131676-1.

Kostryukova AM, Krupnova TG, Mashkova IV, Gavrilkina SV, Egorov NO. 2018. Phytoplankton diversity in three lakes of South Ural, Russia. Biodiversitas 19 (4): 1459-1467. DOI: 10.13057/biodiv/d190436.

Krebs CJ. 1989. Experimental Analysis of Distribution of Abundance Third Edition. Harper and Row Publisher, New York.

Leidonald R, Muhtadi A, Lesmana I, Harahap ZA, Rahmadya A. 2019. Profiles of temperature, salinity, dissolved oxygen, and $\mathrm{pH}$ in Lakes. IOP Conf Ser: Earth Environ Sci 260: 012075. DOI: 10.1088/17551315/260/1/012075.

Letakova M, Frankova M, Poulickova A. 2018. Ecology and applications of freshwater epiphytic diatoms-review. Cryptogamie, Algologie 39 (1): 3-22. DOI: $10.7872 / \mathrm{crya} / \mathrm{v} 39$.iss1.2018.3.

Liyana SH, Sari LA, Dewi NN, Masithah ED, Sahidu AM, Pursetyo KT. 2019. Distribution patterns and the biomass of bivalves at Segoro Tambak estuary, Sedati, Sidoarjo, East Java. IOP Conf Ser: Earth Environ Sci 236: 012043. DOI: 10.1088/1755-1315/236/1/012040.

Ludwig JA, Reynolds JF. 1988. Statistical Ecology A Primer on Methods and Computing. A Wiley Interscience Publication, Canada.

Mann DG, Crawford RM, Round FE. 2016. Bacillariophyta. Handbook of the Protists. Springer, Netherland.

Martins A, Marques F, Cameira M, Santos E, Badenes S, Costa L, Verdelho B, Caetano NS, Mata TM. 2018. Water footprint of microalgae cultivation in photobioreactor. Energy Procedia 153: 426431. DOI: 10.1016/j.egypro.2018.10.031.

Martsenyuk V, Petruk VG, Kvaternyuk SM, Pohrebennyk VD, Bezusiak YI, Petruk RV, Klos-Witkowska A. 2016. Multispectral control of water bodies for biological diversity with the index of phytoplankton. $16^{\text {th }}$ International Conference on Control: Automation and Systems (ICCAS): 988-993. DOI: 10.1109/ICCAS.2016.7832429.

Mason CF. 1981. Biology Freshwater Pollution. $2^{\text {nd }}$ ed. Longman Scientific and Technical, New York.

Melati VH, Sari LA, Cahyoko Y, Arsad S, Pursetyo KT, Dewi NN, Idris MH. 2021. Gastropod community structure as environmental change signals for tropical status in Sedati Waters, Indonesia. Ecol Eng Environ Technol 22 (3): 82-90.

Melsasail K, Awan A, Papilaya PM, Rumahlatu D. 2018. The ecological structure of macroalgae community (seagrass) on various zones in the coastal waters of Nusalaut Island, Central Maluku District, Indonesia. AACL Bioflux 11 (4): 957-966.

Nashaat MR, Merhoon KA, Salman SK, Abbas EK, Ali EH. 2019. Impact of al-rasheed power plant effluents on phytoplankton biodiversity in Tigris River, Southern Baghdad. J Phys: IOP Conf Ser 1234 (012064): 1-13. DOI: 10.1088/1742-6596/1234/1/012064.

Nuhu AA. 2013. Spirulina (Arthrospira): An important source of nutritional and medicinal compounds. J Mar Biol 1 (325636): 1-8. DOI: $10.1155 / 2013 / 325636$ 
Nursyam H. 2017. Aquatic environmental quality survey on turtle conservation at Bajulmati beach Malang District East Java Indonesia. Ponte 73 (2): 46-54. DOI: 10.21506/j.ponte.2017.2.3.

Pacheco MF, Hoeltz M, Moraes MSA, Schneider RCS. 2015. Microalgae: Cultivation techniques and wastewater phytoremediation. J Environ Sci Health Part A Toxic 50 (6): 585-601. DOI: 10.1080/10934529.2015.994951.

Parker S, Lafreniere A, Stewart M, Balsley N. 2018. AOS Protocol and Procedure: Periphyton and Phytoplankton Sampling. National Ecological Observatory Network, USA.

Perwira IY, Ulinuha D. 2014. Phytoplankton diversity as ecological indicator in Jimbaran bay waters. Ecotrophic 1 (1): 18-27.

Pettit NE, Ward DP, Adame F, Valdez DG, Bunn SE. 2016. Influence of aquatic plant architecture on epiphyte biomass on a tropical river floodplain. Aquat Bot 129: 35-43. DOI 10.1016/j.aquabot.2015.12.001.

Pratama PS, Wiyanto DB, Faiqoh E. 2017. Struktur komunitas perifiton pada lamun jenis Thalassia hemprichii dan Cymodocea rotundatta di Kawasan Pantai Sanur. J Mar Aquat Sci 3 (1): 123-133. DOI: 10.24843/jmas.2017.v3.i01.123-133. [Indonesian]

Putrianti DP, Setyawati TR, Yanti AH. 2015. Keragaman limno fitoplankton di danau Lait Kecamatan Tayan Hilir Kabupaten Sanggau. Protobiont 4 (2): 18-29. [Indonesian]

Radwan EH, Fahmy GH, Allah M, Saber K, Eldin M. 2017. The impact of some organic and inorganic pollutants on freshwater (Rashid branch river Nile) Egypt. J Adv Biol 10 (2): 2133-2145. DOI: 10.24297/jab.v10i2.6481

Salahi T, Pourbabaei H, Salahi M, Karamzadeh S. 2017. An investigation on plant species composition and diversity in the coniferous and broadleaved plantations: Case study of Bibi Yanlu Forest Park, Astara, Iran. Biodiversitas 18 (3): 958-963. DOI: 10.13057/biodiv/d180313.

Saputra H, Rachimi, Prasetio E. 2018. Status perairan Sungai Kapuas Kota Pontianak untuk budidaya ikan berdasarkan bioindikator perifiton. Jurnal Ruaya 8 (2): 63-69. DOI: 10.29406/rya.v6i02.1014 [Indonesian]

Sari LA, Sari PDW, Nindarwi DD, Arsad S, Affandi M. 2019a. Harmfu algae identification in Bomo water environment, Banyuwangi, East Java, Indonesia. Ecol Environ Conserv 25 (July Suppl Issue): S26S31.

Sari LA, Pursetyo KT, Arsad S, Masithah ED, Setiawan E, Affandi M. $2019 \mathrm{~b}$. The effect of nutrient abundance on distribution of Cyanobacteria and chlorophyll-A in Sedati Water, Sidoarjo. Pollut Res 38 (August Suppl Issue): S27-S32.

Schofield KA, Alexander LC, Ridley CE, Vanderhoof MK, Fritz KM, Autrey BC, DeMesster JE, Kepner WG, Lane CR, Leibowitz SG, Pollard AI. 2018. Biota connects aquatic habitats throughout freshwater ecosystem mosaics. J Am Water Resour Assoc 54 (2): 372-399. DOI: 10.1111/1752-1688.12634.

Sevindik TO, Altundal E, Kucuk F. 2015. The seasonal and spatial distribution of the phytoplankton of a mesotrophic lake related to certain physical and chemical parameters. Ekoloji 24 (97): 14-23. DOI: 10.5053/ekoloji.2015.09.

Sihombing VS, Gunawan H, Sawitri R. 2017. Diversity and community structure of fish, plankton and benthos in Karangsong mangrove conservation areas Indramayu West java Indonesia. Biodiversitas 18 (2): 601-608. DOI: $10.13057 /$ biodiv/d180222.
Sournia A. 1978. Phytoplankton Manual. Unesco, International Institute for Education Planning, France.

Suryani SAMP, Arya IW, Suparta IM. 2018. Pollution with saprobic index and nutrition value coefficient of fish. Intl J Life Sci 2 (2): 3041. DOI: $10.29332 /$ ijls.v2n2.134.

Suryono T, Sudarso J. 2019. Hubungan komposisi dan kelimpahan perifiton dengan kualitas air di Sungai dan Danau Oxbow di Palangka Raya pada kondisi air dangkal. Limnotek Perairan Darat Tropis di Indonesia 26 (1): 23-38. DOI: 10.14203/limnotek.v26i1.192 [Indonesian]

Tan WK, Beh WC. 2015. Water quality monitoring using biological indicator in Cameron Highlands Malaysia. J Sustain Develop 8 (3): 28-42. DOI: 10.5539/jsd.v8n3p28.

Trias R, Garcia-Liedo A, Sanchez N, Lopez-Jurado JL, Hallin S, Baneras L. 2011. Abundance and composition of epiphytic bacterial and archaeal ammonia oxidizers of marine red and brown macroalgae. Appl Environ Biol 78 (2): 381-325. DOI: 10.1128:AEM.05904-11.

Tungka AW, Haeruddin H, Ain C. 2017. Concentration of nitrate and orthophosphate at Banjir Kanal Barat Estuary and their relationship with the abundance of Harmful Algae Blooms. Saintek Perikanan: Indon J Fish Sci Technol 12 (1):40-46. DOI: 10.14710/ijfst.12.1.4046 [Indonesian]

Ulfah M, Fajri SN, Naisr M, Hamsah K, Purnawan S. 2019. Diversity, evenness and dominance index reef fish in Krueng Raya Water Aceh Besar. IOP Conf Ser: Earth Environ Sci 348: 012074. DOI 10.1088/1755-1315/348/1/012074.

Valiente-Banuet A, Aizen MA, Alcantara JM, Arroyo J, Cocucci A, Galetti M, García MB, García D, Gómez JM, Jordano P, Medel R, Navarro L, Obeso JR, Oviedo R, Ramírez N, Rey PJ, Traveset A, Verdú M, Zamora R. 2015. Beyond species loss: The extinction of ecological interactions in changing world. Funct Ecol 29 (3): 299307. DOI: $10.1111 / 1365-2435.12356$.

Wersal RM, Madsen JD. 2013. Influences of light intensity variations on growth and characteristics of Myriophyllum aquaticum. J Freshw Ecol 28 (2): 147-164. DOI: 10.1080/02705060.2012.722067.

Whitton BA. 1975. River Ecology. Blackwell Scientific Publications, Oxford, UK.

Wilhm JL, Dorris TC. 1968. Biological parameters for water quality criteria. BioScience 18 (6): 477-481. DOI: $10.2307 / 1294272$.

Wilhm JL, Dorris TC. 2007. Species Diversity of Benthic Macroinvertebrates in A Stream Receiving Domestic and Oil Refinery Effluents. Phytoplankton Diversity Index with Reference to Mucalinda Serovar Bodh-gaya. 12 $2^{\text {th }}$ World Lack Conference: American Midland Naturalist, Taal, India.

Woo Jo S, Do J, Kang NS, Park JM, Lee JH, Kim HS, Hong JW, Yoo H. 2020. Isolation, identification, and biochemical characteristics of a cold-tolerant Chlorella vulgaris KNUA007 isolated from King George Island, Antarctica. J Mar Sci Eng 8: 935. DOI: 10.3390/jmse8110935.

Xue Y, Song J, Zhang Y, Kong F, Wen M, Zhang G. 2016. Nitrate pollution and preliminary source identification of surface water in a semi-arid river basin, using isotopic and hydrochemical approaches. Water 8 : 328. DOI: 10.3390/w8080328.

Ye YY, Luo Y, Wang Y, Lin M, Xiang P, Ashraf MA. 2017. Relation between diversity of phytoplankton and environmental factors in waters around Nanri Island. Appl Ecol Environ Res 15 (3): 241-252. DOI: 10.15666/aeer/1503_241252. 